\title{
A New Method for Inducing Synchronous Growth of Dictyostelium discoideum Cells Using Temperature Shifts
}

\author{
By YASUO MAEDA \\ Biological Institute, Faculty of Science, Tohoku University, Aoba, Sendai 980, Japan
}

(Received 24 July 1985 ; revised 12 December 1985)

\begin{abstract}
A method employing temperature shifts was used to obtain extremely synchronous growth of amoebae of Dictyostelium discoideum Ax-2 in axenic medium. When exponentially growing cells at $22.0^{\circ} \mathrm{C}$ were shifted to $11.5^{\circ} \mathrm{C}$ and shaken for $20 \mathrm{~h}$, they exhibited good synchrony upon further culture at $22.0{ }^{\circ} \mathrm{C}$. A relatively narrow range of low temperature (about $11.5^{\circ} \mathrm{C}$ ) and of treatment time $(20 \pm 0.5 \mathrm{~h})$ was necessary for inducing the best synchrony. This temperatureshift method is simple and practical and should be useful for detailed cellular and molecular investigations of growth regulation and of the relationship between the cell cycle and the differentiation of developing cells.
\end{abstract}

\section{INTRODUCTION}

The cellular slime mould Dictyostelium discoideum normally grows as solitary amoebae by feeding on bacteria and multiplies by binary fission. Cells of the mutant strain Ax-2 can be grown easily in the laboratory either axenically (Watts \& Ashworth, 1970) or in association with bacteria (Sussman, 1966). The axenically grown cells show a doubling time of about $7 \cdot 2 \mathrm{~h}$. All analyses of the Dictyostelium cell cycle have been done with axenic cells (Katz \& Bourgignon, 1974; Zada-Hames \& Ashworth, 1978a, $b$; Weijer et al., 1984a). The results of one study indicate that axenically growing $A x-2$ cells have a cell cycle with a $G_{1}$ phase of $1.5 \mathrm{~h}$, an $S$ phase of $2.5 \mathrm{~h}$ and $\mathrm{a} \mathrm{G}_{2}$ phase of $4.0 \mathrm{~h}$ (Zada-Hames \& Ashworth, 1978 a). In contrast, however, Weijer et al. $(1984 a)$ found no $\mathrm{G}_{1}$ period and an $\mathrm{S}$ phase lasting $30 \mathrm{~min}$ or less, with most of the cell cycle being in the $G_{2}$ phase of $6.5 \mathrm{~h}$.

Despite numerous attempts to obtain synchronous culture systems by a variety of means, many workers have failed to obtain reproducible results; standard methods are either ineffective or result in only partial synchrony. It has been claimed that partial synchrony can be obtained by transferring stationary phase Ax-2 cells into fresh growth medium (Zada-Hames \& Ashworth, $1978 a$; Weijer et al., 1984a), but this method was found to be unsatisfactory in the present study.

To examine the cellular and molecular basis of the cell cycle and its relationship to the developmental fate of cells, methods must be established for producing more complete synchrony. Such a method is described here which relies on temperature shifts during shaking to induce synchronous growth.

\section{METHODS}

Organisms and culture. Dictyostelium discoideum Ax-2 was used in all the experiments, and was grown axenically in HL-5 medium containing $1.5 \%$ glucose according to Watts \& Ashworth (1970). At $22^{\circ} \mathrm{C}$, the cells had a doubling time of $7 \cdot 2 \pm 0.3 \mathrm{~h}$ in the density range $2 \times 10^{5}$ to $6 \times 10^{6} \mathrm{cells} \mathrm{ml}^{-1}$.

Transfer of stationary-phase cells into fresh medium. To re-examine the observations reported by Weijer et al. $(1984 a)$, cells $\left(1 \cdot 2-1.4 \times 10^{7} \mathrm{ml}^{-1}\right)$ at the early stationary phase were diluted into fresh medium at a density of $0 \cdot 5$ $1.0 \times 10^{6}$ cells ml-1 and the increase in cell number was followed. There was generally a considerable number of multinucleate (large) cells, which eventually divided to form several mononucleate cells during shaking. Since the ratio of multinucleate cells to mononucleate cells seemed to increase considerably as the relative volume of the cell 


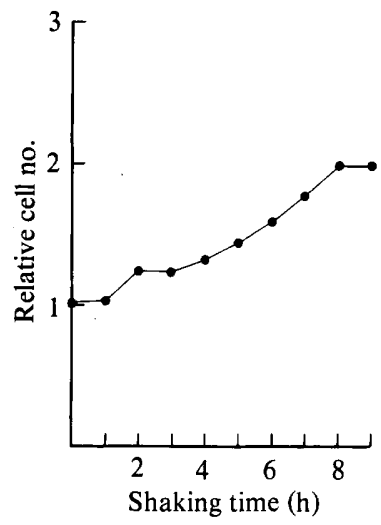

Fig. 1. Growth of stationary-phase $D$. discoideum $A x-2$ cells after transfer into fresh growth medium. Cells grown at $22.0 \pm 0.2^{\circ} \mathrm{C}$ to a density of $1.2 \times 10^{7} \mathrm{ml}^{-1}$ were diluted into fresh medium at a density of $6 \times 10^{5}$ cells ml-1 and shaken at $22 \cdot 0 \pm 0 \cdot 2^{\circ} \mathrm{C}$. Cells doubled with two steps of increase in cell number.

suspension in the shaking flask was increased, $10 \mathrm{ml}$ of cell suspension was shaken in a $100 \mathrm{ml}$ Erlenmeyer flask at 150 r.p.m.

Temperature-shift procedures. Exponentially growing cells $\left(0.5-1 \cdot 0 \times 10^{6} \mathrm{ml}^{-1}\right)$ at $22.0 \pm 0.2^{\circ} \mathrm{C}$ were transferred to a shaker at $10-12^{\circ} \mathrm{C}$. Under these conditions, the cells were cooled to the lower temperature within $20 \mathrm{~min}$. After various periods of shaking, the cultures were warmed to $22.0^{\circ} \mathrm{C}$ within $1 \mathrm{~min}$ by immersion in a water-bath at $25^{\circ} \mathrm{C}$, followed by shaking at $22 \cdot 0^{\circ} \mathrm{C}$. Cell counts were taken at $1 \mathrm{~h}$ intervals using a haematocytometer. To make the counts accurate, the number of cells (at least 500 cells) contained in the whole measure of the haematocytometer was counted for each sample.

DNA-specific staining of cells. Cells were fixed in methanol and air-dried on cleaned coverslips. The coverslips were incubated for $10 \mathrm{~min}$ in $200 \mathrm{mM}-\mathrm{KCl}$ and then stained for $1 \mathrm{~h}$ with the DNA-specific fluorophore DAPI $\left(0.5 \mu \mathrm{g} \mathrm{ml}^{-1}\right.$ in McIlvain's buffer, $\left.\mathrm{pH} 7.0\right)$, as reported by Leeman \& Rush (1982). After a brief wash in the same buffer without DAPI, they were mounted in a $20 \%(\mathrm{v} / \mathrm{v})$ glycerol solution dissolved in McIlvain's buffer. The fluorescence and number of nuclei in cells were monitored under a fluorescence microscope using UV excitation.

\section{RESULTS AND DISCUSSION}

\section{Growth kinetics of stationary-phase cells after transfer into fresh growth medium}

When Ax-2 cells $\left(1.2-1.4 \times 10^{7} \mathrm{ml}^{-1}\right)$ grown to the early stationary phase were diluted in fresh medium at a density of $0.5-1.0 \times 10^{6}$ cells $\mathrm{ml}^{-1}$, they exhibited a bimodal increase in cell number during their first doubling (Fig. 1). The first increase in cell number occurred in a period of $1 \mathrm{~h}$ after a lag phase of about $1 \mathrm{~h}$. After a further $1 \mathrm{~h}$, the cell number increased gradually over a 4 to $5 \mathrm{~h}$ period. In all cases (10 experiments), the cell doubling occurred in at least two steps, though the pattern varied somewhat from experiment to experiment. This variability may depend upon the ratio of multinucleate cells at the time of dilution, since the initial increase in cell numbers could be largely attributed to the break-up of multinucleate cells. Consistent with this view, cell populations with a higher ratio of multinucleate cells seemed to show a more rapid increase in number during the first 1 to $2 \mathrm{~h}$ period.

These findings indicated that, apart from the problem of multinucleate cells, stationary-phase cells were arrested in a broad distribution of points in the early $\mathrm{G}_{2}$ phase. This seems to be somewhat different from the previous observation reported by Weijer et al. (1984a), who demonstrated that stationary-phase cells are arrested at a relatively critical point of the late $\mathrm{G}_{2}$ phase and grow unimodally in fresh medium over a 2 to $3 \mathrm{~h}$ period after a lag phase of $1-2 \mathrm{~h}$. Although the reason for this difference is unknown, it may at least partly be due to the difference in methods of counting the cell number. Weijer et al. (1984a) made cell counts using an electronic particle counter. Ax-2 cells sometimes form cell clumps during shaking, and also a multinucleate cell often divides into several smaller cells without separating into single cells. Smaller cell fragments without nuclei can also form by pinching off from axenically growing 


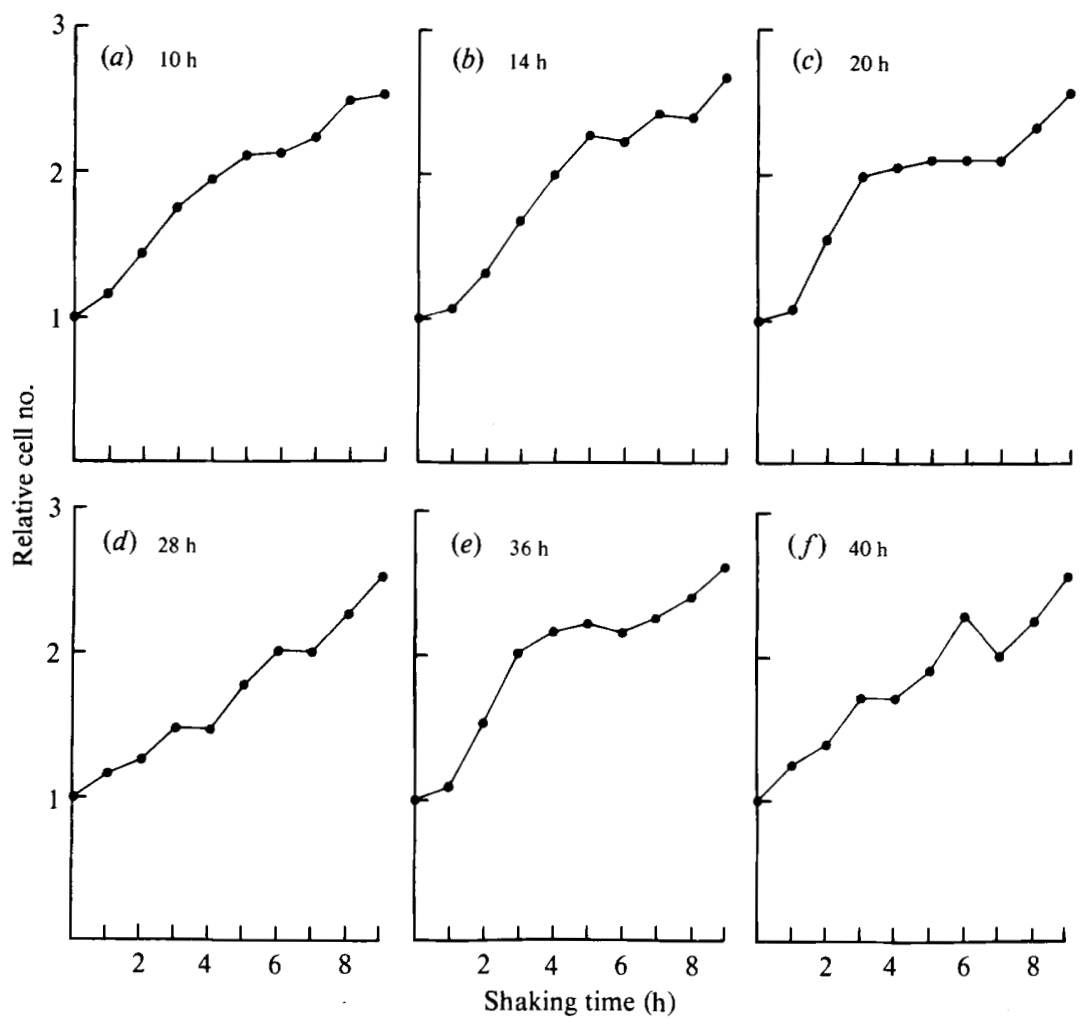

Fig. 2. Growth of $\mathrm{Ax}-2$ cells following various periods of incubation at low temperature $\left(11 \cdot 5^{\circ} \mathrm{C}\right)$. Cells $\left(3-5 \times 10^{5} \mathrm{ml}^{-1}\right)$ growing exponentially at $22.0 \pm 0.2^{\circ} \mathrm{C}$ were shifted to $11.5 \pm 0.2^{\circ} \mathrm{C}$ and shaken for $10 \mathrm{~h}(a), 14 \mathrm{~h}(b), 20 \mathrm{~h}(c), 28 \mathrm{~h}(d), 36 \mathrm{~h}(e)$ or $40 \mathrm{~h}(f)$. This was followed by shaking at $22 \cdot 0 \pm 0 \cdot 2^{\circ} \mathrm{C}$. The best synchrony was obtained after $20 \mathrm{~h}$ at the low temperature.

Ax-2 cells. Such a cell clump or a cell fragment will undoubtedly be recorded by the electronic counter as one cell, thus leading to errors in the cell number. Cell counts with a haematocytometer, as done in the present study, should give better results, because even the cell number in clumps can be correctly determined under a phase-contrast microscope.

\section{Temperature-shifts for growth synchronization}

Since the above transfer experiments resulted in partial synchrony, other methods were tested in the hope of obtaining more completely synchronous growth of cells. When Ax-2 cells growing exponentially at $22 \pm 0.2^{\circ} \mathrm{C}$ were shifted to $11.5 \pm 0.2^{\circ} \mathrm{C}$, shaken for $20 \mathrm{~h}$, and then shifted to $22 \cdot 0 \pm 0.2^{\circ} \mathrm{C}$, they generally expressed good synchrony; cell doubling occurred over about a $2 \mathrm{~h}$ period after a lag phase of about $1 \mathrm{~h}$ (Fig. $2 \mathrm{c}$ ). With $19 \mathrm{~h}$ or $21 \mathrm{~h}$ of the low-temperature treatment there was reduced synchrony. Thus, the growth patterns varied depending upon the period of the low-temperature treatment (Fig. 2). Synchrony indices $(F)$ as described by Blumenthal \& Zahler (1962) were plotted against the treatment time at $11.5^{\circ} \mathrm{C}$ (Fig. 3). The best synchrony was obtained after about $20 \mathrm{~h}$ of the treatment, with shorter periods resulting in partial synchrony. Longer low-temperature treatment led to various effects; synchrony was lost after $28 \mathrm{~h}$ of treatment, but regained after about $36 \mathrm{~h}$ of treatment, and lost again after $40 \mathrm{~h}$ of treatment. Essentially the same results were obtained by treatment of the cells at $11.0 \pm 0.2^{\circ} \mathrm{C}$, though the extent of cell synchrony seemed to be slightly inferior to that at $11.5 \pm 0.2^{\circ} \mathrm{C}$. The treatment of the cells at lower temperatures, such as $10.0-10.5^{\circ} \mathrm{C}$, caused considerable deterioration of synchrony (Fig. 4). The cells which had been treated for $20 \mathrm{~h}$ at $10.0 \pm 0.2^{\circ} \mathrm{C}$ exhibited a bimodal growth curve somewhat similar to that shown in Fig. 1. A longer period 


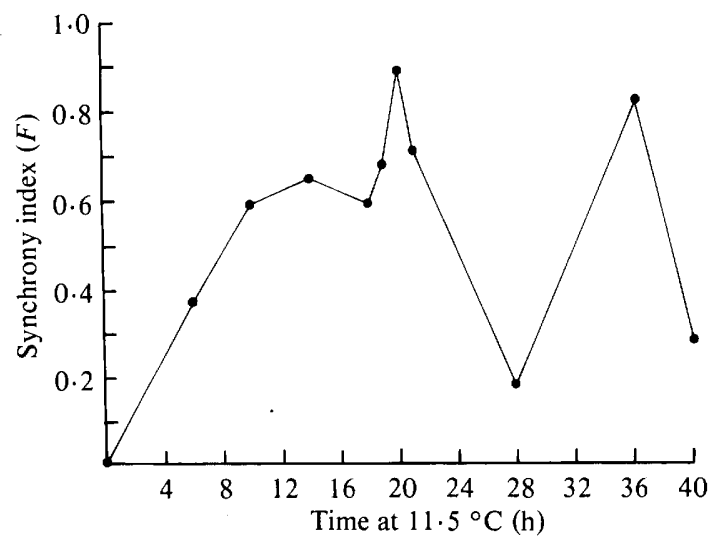

Fig. 3. Synchrony indices $(F)$ plotted against treatment time at $11.5^{\circ} \mathrm{C}$. Ax-2 cells growing exponentially at $22.0^{\circ} \mathrm{C}$ were shifted to $11.5^{\circ} \mathrm{C}$. After the designated periods of shaking, they were shifted to $22.0^{\circ} \mathrm{C}$, and cell counts taken at $1 \mathrm{~h}$ intervals. Synchrony indices $(F)$ were determined according to Blumenthal \& Zahler (1962), using the formula $F=N / N_{0}-2^{t / g}$, where the number of cells in a culture increases from $N_{0}$ to $N$ in an interval $t$ less than one generation time $g$.

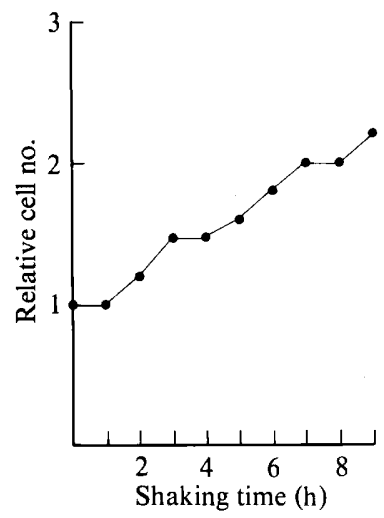

Fig. 4. Bimodal increase in the number of $\mathrm{Ax}-2$ cells after $20 \mathrm{~h}$ of treatment at $10 \cdot 0^{\circ} \mathrm{C}$. Cells $\left(5 \times 10^{5} \mathrm{ml}^{-1}\right)$ growing at $22 \cdot 0 \pm 0.2^{\circ} \mathrm{C}$ were shifted to $10.0 \pm 0.2^{\circ} \mathrm{C}$ and shaken for $20 \mathrm{~h}$. This was followed by shaking at $22 \cdot 0 \pm 0 \cdot 2^{\circ} \mathrm{C}$. The cells exhibit two steps in the doubling of their number, with growth kinetics similar to that shown in Fig. 1.

$(24 \mathrm{~h})$ at $10 \cdot 0^{\circ} \mathrm{C}$ gave essentially the same growth kinetics. This was also the case for cells treated at $10 \cdot 5 \pm 0 \cdot 2^{\circ} \mathrm{C}$. On the other hand, cells treated at $12 \cdot 0 \pm 0 \cdot 2^{\circ} \mathrm{C}$ gave a unimodal growth curve, but the synchrony was less than that shown in Fig. $2(c)$. Thus, a relatively narrow range of both temperature (about $11.5^{\circ} \mathrm{C}$ ) and treatment time $(20 \pm 0.5 \mathrm{~h})$ was of extreme importance for inducing subsequent synchronous growth. There may be a critical point in the late $G_{2}$ phase which cells have difficulty passing at $11.5^{\circ} \mathrm{C}$ and another point in the early $\mathrm{G}_{2}$ phase which becomes restrictive at around $10.0^{\circ} \mathrm{C}$, and combined these produce the bimodal growth curve seen at the lower temperature.

In order to examine the temporal change of nuclearity in a synchronized cell population, the cells shaken for $20 \mathrm{~h}$ at $11.5^{\circ} \mathrm{C}$ were shifted to $22.0^{\circ} \mathrm{C}$, and stained with DAPI after various periods of shaking. As shown in Table 1, there was only a slight change in the ratio of mononucleate cells to binucleate cells over the whole course of the experiment, though the ratio increased slightly in the first $3 \mathrm{~h}$ of culture during which almost all cells completed division. The ratio then declined rapidly to the starting level during the next $1 \mathrm{~h}$ of culture. There was no significant change in the proportion of cells with three or more nuclei during the experiment. 
Table 1. Change in nuclearity of vegetative cells during synchronized cell-cycle phases in D. discoideum $A x-2$

D. discoideum Ax-2 cells growing exponentially at $22.0{ }^{\circ} \mathrm{C}$ were shifted to $11.5^{\circ} \mathrm{C}$ and shaken for $20 \mathrm{~h}$ to synchronize their cell cycles, followed by a shift to $22 \cdot 0^{\circ} \mathrm{C}$. After the indicated periods, cells were fixed and stained with DAPI, as described in Methods. Cells with one, two or more nuclei were counted separately. A minimum of 1000 cells were counted for each sample. Values are means \pm SD of three determinations.

\begin{tabular}{|c|c|c|c|}
\hline \multirow{3}{*}{$\begin{array}{l}\text { Time after shift } \\
\text { to } 22 \cdot 0^{\circ} \mathrm{C}(\mathrm{h})\end{array}$} & \multicolumn{3}{|c|}{ Percentage of cells } \\
\hline & \multicolumn{3}{|c|}{ No. of nuclei per cell: } \\
\hline & 1 & 2 & $\geq 3$ \\
\hline$-20^{*}$ & $62 \cdot 3 \pm 3 \cdot 1$ & $34 \cdot 3 \pm 2 \cdot 9$ & $3.4 \pm 1.6$ \\
\hline 0 & $65 \cdot 3 \pm 3.4$ & $32 \cdot 4 \pm 2 \cdot 8$ & $2 \cdot 3 \pm 1 \cdot 4$ \\
\hline 1 & $69.5 \pm 3.6$ & $26 \cdot 6 \pm 2.4$ & $3.9 \pm 1.7$ \\
\hline 2 & $70.7 \pm 3.5$ & $24.5 \pm 2.5$ & $4.8 \pm 1.9$ \\
\hline 3 & $76 \cdot 3 \pm 3.6$ & $21 \cdot 1 \pm 2 \cdot 3$ & $2 \cdot 7 \pm 1 \cdot 1$ \\
\hline 4 & $63.7 \pm 3 \cdot 3$ & $32.4 \pm 2 \cdot 4$ & $3.9 \pm 1.4$ \\
\hline 5 & $64 \cdot 1 \pm 3.4$ & $32 \cdot 2 \pm 2 \cdot 5$ & $3.6 \pm 1.5$ \\
\hline 6 & $62.4 \pm 3.2$ & $32 \cdot 3 \pm 2 \cdot 3$ & $5.3 \pm 1.8$ \\
\hline 7 & $63 \cdot 3 \pm 3 \cdot 7$ & $33 \cdot 0 \pm 2.6$ & $3.8 \pm 1.6$ \\
\hline 8 & $60 \cdot 9 \pm 4 \cdot 2$ & $33 \cdot 1 \pm 3 \cdot 1$ & $5 \cdot 8 \pm 2 \cdot 1$ \\
\hline
\end{tabular}

* Cells just before shift-down to $11.5^{\circ} \mathrm{C}$ were taken as an unsynchronized sample.

Staining with DAPI revealed that almost all the nuclei contained twice the amount of DNA present in daughter nuclei of anaphase mitotic figures. Weijer et al. (1984a) reported that Ax-2 cells lack a $G_{1}$ phase and have only a short $S$ phase, and consistent with this, cells with half the interphase nuclear DNA content were rare even in actively dividing cell populations.

In an attempt to further improve cell synchrony, post-mitotic cells, synchronized by growth at $11.5^{\circ} \mathrm{C}$ for $20 \mathrm{~h}$ and $22^{\circ} \mathrm{C}$ for $4 \mathrm{~h}$, were re-shifted to $11.5 \pm 0.2^{\circ} \mathrm{C}$. After various periods of shaking at the low temperature, the growth kinetics of the cells at $22 \cdot 0 \pm 0 \cdot 2^{\circ} \mathrm{C}$ were analysed. Fairly synchronous populations were repeatedly obtained, for example, after 6 or $13 \mathrm{~h}$ of the lowtemperature treatment, but cell synchrony was almost completely lost after 8-10 h of the treatment (Fig. 5). Cell synchrony could not be improved by a second treatment at the low temperature, which seemed to cause progressive deterioration of the synchronization. A marked difference in growth kinetics was observed between the first and the second treatments at $11.5 \pm 0.2^{\circ} \mathrm{C}$ (Fig. 6). Cell multiplication was almost completely inhibited during the first $20 \mathrm{~h}$ period at $11.5^{\circ} \mathrm{C}$, but after $4 \mathrm{~h}$ at $22^{\circ} \mathrm{C}$ to allow a cell doubling, followed by a return to $11.5^{\circ} \mathrm{C}$, the cell number rose at an increasing rate. These findings suggest that cells may slowly adapt to $11.5^{\circ} \mathrm{C}$ and eventually resume growth, thus interfering with synchrony. Possibly, the isolation of clones that are especially sensitive to the low temperature and/or the elimination of multinucleate cells may be required to obtain more completely synchronized cell populations.

It is of interest to note that the cells kept at $11.5^{\circ} \mathrm{C}$ for various periods of time go through cycles of synchronous and less synchronous division when shifted to $22 \cdot 0^{\circ} \mathrm{C}$ (Figs 2,3 and 5 ). Though there is little division when cells are incubated at $11.5^{\circ} \mathrm{C}$ (Fig. 6), it is still possible that the nuclear cycle continues under these conditions, and if this occurred it would result in an increased multinuclearity or ploidy. To test this possibility, the cells shaken at $11.5^{\circ} \mathrm{C}$ for various periods were stained with DAPI (Table 2). The results showed that there was scarcely any change in the nuclearity during the periods examined, though the ratio of binucleate cells to mononucleate cells seemed to increase slightly during the first $6 \mathrm{~h}$ of culture at $11.5^{\circ} \mathrm{C}$. Such an increase could be related to the small amount of cell division observed during further culture (between $8 \mathrm{~h}$ and $16 \mathrm{~h}$ shown in Fig. 6). From the observations on fluorescence intensity of nuclei, it was found that almost all the cells had one or more interphase nuclei, each of which contained twice the amount of DNA present in daughter nuclei of anaphase mitotic figures, regardless of the treatment time at $11.5^{\circ} \mathrm{C}$. These findings indicate that neither multinuclearity nor ploidy increases during shaking at $11.5^{\circ} \mathrm{C}$. Thus the cell division cycle does not seem to be 


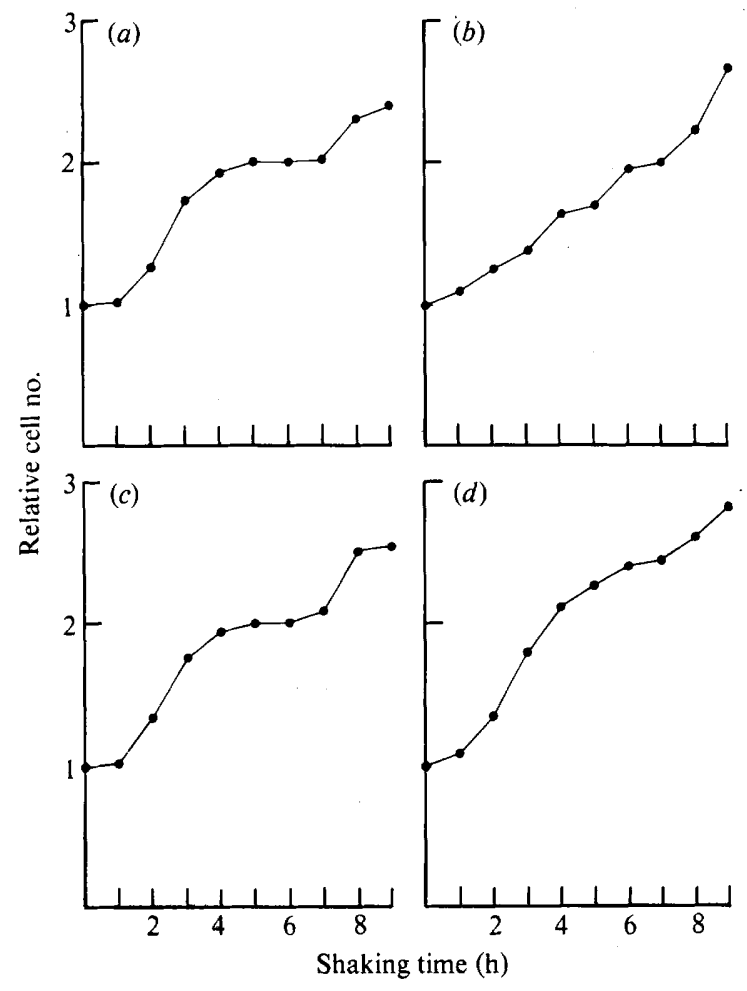

Fig. 5. Effects of a second $11.5^{\circ} \mathrm{C}$ treatment on growth synchrony of $\mathrm{Ax}-2$ cells. Cell suspensions just after mitosis, obtained by growth first at $11.5 \pm 0.2^{\circ} \mathrm{C}$ for $20 \mathrm{~h}$ and then at $22.0 \pm 0.2^{\circ} \mathrm{C}$, for $4 \mathrm{~h}$ were reshifted to $11.5 \pm 0 \cdot 2^{\circ} \mathrm{C}$. After $6 \mathrm{~h}(a), 8 \mathrm{~h}(b), 13 \mathrm{~h}(\mathrm{c})$ and $20 \mathrm{~h}(d)$ of shaking at the low temperature, the cells were restored to $22^{\circ} \mathrm{C}$ and their growth followed. Relatively good synchrony was attained after $6 \mathrm{~h}$ or $13 \mathrm{~h}$ of the second treatment at $11.5^{\circ} \mathrm{C}$.

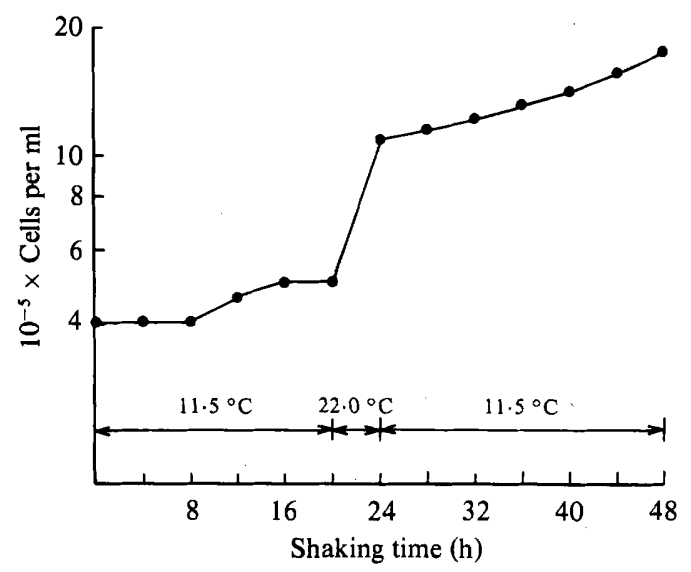

Fig. 6. Growth kinetics of Ax-2 cells during the first and second treatments at $11 \cdot 5^{\circ} \mathrm{C}$. Cells growing exponentially at $22.0 \pm 0.2^{\circ} \mathrm{C}$ were shifted to $11.5 \pm 0.2^{\circ} \mathrm{C}$ and shaken for $20 \mathrm{~h}$. They were then shifted to $22.0 \pm 0.2^{\circ} \mathrm{C}$ and shaken for $4 \mathrm{~h}$, and then returned to $11.5 \pm 0.2^{\circ} \mathrm{C}$ and shaken for $24 \mathrm{~h}$. Note the marked difference in growth kinetics between the first and the second cultures at $11.5^{\circ} \mathrm{C}$. 
Table 2. Effect of a low-temperature treatment on the nuclearity of vegetative cells of

$$
\text { D. discoideum } A x-2
$$

D. discoideum Ax-2 cells growing exponentially at $22.0{ }^{\circ} \mathrm{C}$ were shifted to $11.5^{\circ} \mathrm{C}$ and shaken for the indicated periods. The percentage of cells with one, two or more nuclei was determined, as for Table 1 . Values are means \pm SD of three determinations.

\begin{tabular}{|c|c|c|c|}
\hline \multirow{3}{*}{$\begin{array}{l}\text { Time after shift } \\
\text { to } 11.5^{\circ} \mathrm{C}(\mathrm{h})\end{array}$} & \multicolumn{3}{|c|}{ Percentage of cells } \\
\hline & \multicolumn{3}{|c|}{ No. of nuclei per cell: } \\
\hline & 1 & 2 & $\geq 3$ \\
\hline 0 & $72 \cdot 4 \pm 3 \cdot 5$ & $24 \cdot 5 \pm 2 \cdot 3$ & $3 \cdot 1 \pm 1 \cdot 4$ \\
\hline 6 & $61.6 \pm 3.2$ & $32.9 \pm 2.5$ & $5.5 \pm 1.9$ \\
\hline 12 & $73.4 \pm 3.7$ & $22 \cdot 3 \pm 2 \cdot 6$ & $4.3 \pm 1.7$ \\
\hline 16 & $74.4 \pm 3.5$ & $23.5 \pm 2.5$ & $2 \cdot 1 \pm 1 \cdot 1$ \\
\hline 20 & $71 \cdot 0 \pm 3 \cdot 1$ & $25.9 \pm 2.4$ & $3.1 \pm 1.6$ \\
\hline 24 & $71.7 \pm 3.3$ & $25.7 \pm 2.4$ & $2 \cdot 6 \pm 1 \cdot 3$ \\
\hline 28 & $74 \cdot 6 \pm 3 \cdot 9$ & $22 \cdot 0 \pm 2 \cdot 1$ & $3.4 \pm 1.6$ \\
\hline 36 & $71 \cdot 6 \pm 3.4$ & $23.4 \pm 2.2$ & $5.0 \pm 1.8$ \\
\hline 40 & $76 \cdot 9 \pm 4 \cdot 1$ & $19.3 \pm 2.8$ & $3.8 \pm 1.5$ \\
\hline
\end{tabular}

tightly coupled to the nuclear cycle timer at the low temperature. In this connection, it is possible that the periodic appearance of synchrony may be due to cyclical changes in the machinery required for cytokinesis. The time intervals between the two synchronous phases seem to become shorter depending on the length of culture at $11.5^{\circ} \mathrm{C}$, as shown in Figs 2,3 and 5 . This could be related to a speeding up of the cytokinesis timer, possibly due to its adaptation to the low temperature.

The temperature-shift method described here for inducing synchronous growth of Ax-2 cells is very practical because of its simplicity and convenience. It should be useful for detailed investigations of growth regulation. Recently, it has been claimed that cells starved at the early $\mathrm{G}_{2}$ phase of the cell cycle sort out strongly to the anterior prestalk region of the migrating slug (Zada-Hames \& Ashworth, $1978 b$; McDonald \& Durston, 1984; Weijer et al., 1984b, $c$; Durston et al., 1984). It will be interesting to know if this correlation holds true also for cells synchronized by the temperature shift method. Work is also in progress to determine the exact duration of each cell-cycle phase using the temperature-shift method.

I wish to thank Dr N. Haga of Tohoku University for reading and criticising the manuscript. I also gratefully acknowledge Mr T. Ohmori and Mr K. Takahashi for their invaluable help with the cell counts. This work was in part supported by grants-in-aid (no. 60540442) from the Ministry of Education, Science and Culture of Japan and a grant from the Yamada Science Foundation.

\section{REFERENCES}

Blumenthal, L. K. \& Zahler, S. A. (1962). Index for measurement of synchronization of cell population. Science 134, 724.

Durston, A. J., WeiJer, C. J., JongKind, J. F., Verkerk, A., Timmermans, A. \& Kulve, W. T. (1984). A flow fluorimetric analysis of the cell cycle during growth and differentiation in Dictyostelium discoideum. Roux's Archives of Developmental Biology 194, 18-24.

Katz, E. R. \& Bourgignon, L. Y. W. (1974). The cell cycle and its relation to aggregation in the cellular slime mold, Dictyostelium discoideum. Developmental Biology 36, 82-87.

LeEman, U. \& Rush, F. (1982). Cytofluometric determination of DNA base content in plant nuclei and chromosomes by the fluorochromes DAPI and Chromomycin A3. Experimental Cell Research 140, 275-282.

McDonald, S. A. \& Durston, A. J. (1984). The cell cycle and sorting behavior in Dictyostelium discoideum. Journal of Cell Science 66, 195204.

Sussman, M. (1966). Biochemical and genetic methods in the study of cellular slime mold development. In Methods in Cell Physiology, vol. 2, pp. 397-410. Edited by D. M. Prescott. New York \& London: Academic Press.

WATTS, D. J. \& ASHWorth, J. M. (1970). Growth of myxamoebae of the cellular slime mould. Dictyostelium discoideum in axenic medium. Biochemical Journal 119, 171-174.

WeIJer, C. J., DusChl, G. \& DAvid, C. N. (1984a). A revision of the Dictyostelium discoideum cell cycle. Journal of Cell Science 70, 111-131.

WeIJeR, C. J., Duschl, G. \& DAvid, C. N. (1984b). Dependence of cell type proportioning and sorting on cell cycle phase in Dictyostelium discoideum. Journal of Cell Science 70, 133-145. 
Weijer, C. J., McDonald, S. A. \& Durston, A. J. $(1984 c)$. A frequency difference in optical-density oscillations of early Dictyostelium discoideum density classes and its implications for development. Differentiation 28, 9-12.

Zada-HAMES, I. \& AshworTh, J. M. (1978a). The cell cycle during the vegetative stage of Dictyostelium discoideum and its response to temperature change. Journal of Cell Science 32, 1-20.

Zada-Hames, I. \& AshworTh, J. M. (1978b). The cell cycle and its relation to development in Dictyostelium discoideum. Developmental Biology 63, 307-320. 